\title{
China's Three Distinctive Assertions under the 'Nine-dash-line' Claims and the Annex VII Arbitral Tribunal's Interpretation of Article 121 Regarding an Island and Rocks under the 1982 UN Convention on the Law of the Sea
}

\author{
Eiichi Usuki ${ }^{1}$
}

As depicted in the 'Map of Southern Sea' published in 1940 in Japan (MAP 8.1, see below at the end of this article), Japan's 'New Southern Islands' ['shin-nangunto'] might be said to be the prototype of China's 'nine-dash-line', although the former claimed area was limited to the Spratly Islands only (Nánshā Qúndăo). Japan's Cabinet, on 23 December 1939, decided to incorporate the southern part of the South China Sea and made an attempt to assert its sovereignty over all the islands and rocks, including their territorial waters, not only giving Japanese names to several major islands (e.g. 'Nagashima' to the largest one, at the present moment Taiwan's 'Tàipíng Dăo' or 'Itu Aba Island') but also making use of 'seven straight lines' so as to encompass those maritime features by a heptangular zone. ${ }^{3}$ Indeed, from the very start, France and the United

1 Ph.D (Cantab.), LL.M (Hitotsubashi Univ.), B.L and B.L.A (Univ. of Tokyo), Professor of International Law, Department of Asian Area Studies, Graduate School of Daito Bunka University, Japan.

2 ran-in (nanyo) oyobi futsuin zenzu [Complete map of Dutch India (Southern Sea) and French India] (kinreisha, 15 December 1940).

3 [extending from 7 degrees to 12 degrees North (latitude) and between 111 degrees 30 minutes and 117 degrees East (longitude)] Japan's Cabinet, on 23 December 1939, decided to incorporate the southern part of the South China Sea [hereinafter scs]. Japan's Cabinet decision, 23 December 1938; Decree No.3, Government-General, Taiwan, 30 March 1939, and Notification No.122, Government-General, Taiwan, 30 March 1939.kanpo [Government Bulletin] (18 April 1939). It would seem that this incorporation of the New Southern Islands relied on the occupation of no man's land on the basis of an attempt to exploit guano by a Japanese company. 
States staged diplomatic protests against Japan's incorporation of 'shin-nangunto' (the Spratly Islands) into its colony, Taiwan. ${ }^{4}$

Japan's measure of incorporation appears to have been motivated by the 1938 French note verbale conveyed toJapan, informing the French intention to appropriate another group of islands, the Paracel Islands (Xīshā Qúndăo), as France regarded them as res nullius or no man's land, although Imperial China (qing; Ch'ing dynasty) had already, in 1909, intended to appropriate them as islands under its sovereignty, and this Chinese position had been recognized by Japan, and such a status was confirmed by Japan in its note verbale to France (12 July 1938). In December 1938, indeed, Japan's Cabinet decided to incorporate the Paracel Islands, too, but it was not implemented in law (presumably because it would be an action repugnant to Japan's prior confirmation of July 1938 for the Chinese position), while there were the mineral-phosphate mining activities continued by a Japanese company on those Islands, and Japan, as a matter of fact, utilized them for military purposes later in spite of French continual demarches. ${ }^{5}$

In passing, as far as the Pratas Islands (Dōngshā Qúndăo) were concerned, they were already recognized by Japan as islands remaining under Imperial China through the 1909 Japan- Ch'ing Agreement for Handing Over Pratas Island (11 Oct. 1909).

Accordingly, it appears that, even before the Second World War, the status or the sovereignty of the islands in the South China Sea (scs) was unsettled in law, except for the Pratas Islands.

When the Japanese Forces surrendered to the Allied Powers after the Second World War, the islands in the scs, all of sudden, became virtually no man's land (terra nullius). Soon after that, the Republic of China, French Vietnam, the Philippines, British Colony of Sarawak (which became Malaysia) and Indonesia began to compete with one another for recovery or appropriation of territories. Then, Article 2 (f) of the 1951 Treaty of Peace with Japan only provided that Japan shall renounce all rights, titles and claims to the New Southern Islands (Spratly Islands) and to the Paracel Islands. ${ }^{6}$ It means that

4 nihon no kokusaiho jirei kenkyu (3), ryodo [Digest of Japanese Practice in International Law (3), Territory] (Keio Tsushin Co. Ltd., 1990) 65 .

5 Ibid. at 66-67.

6 On 15 August 1951, the People's Republic of China (Zhōu Ẽnlái, Minister of Foreign Affairs) published statements denouncing the draft treaty as a whole, stating that it was illegal and should not be recognized. Besides, the People's Republic of China claimed that it did not refer to the return of the sovereignty over Paracel Islands, Spratly Islands, in particular 'Spratly Island' in the scs, and that they were all part of China. nihon gaiko shuyo bunsho/nenpyo (1) [Main Documents/Chronological Table on the Japanese Diplomacy (1)] 406-411. 
the allocation of territories in this region remained unsettled, and on the other hand, that the paragraph of the 1943 Cairo Declaration to the effect 'that all the territories Japan has stolen from the Chinese, such as Manchuria, Formosa, and the Pescadores, shall be restored to the Republic of China' was only incompletely implemented. ${ }^{7}$

Thus, the sovereignty dispute over the islets in the Spratly Islands and the Paracel Islands remains in limbo, as we witness today. When it comes to sovereignty, the SCS area is regarded as territories which remain unsettled under the post-war deals regarding the allocation or recovery of former occupied territories.

When the People's Republic of China (PRC) was established in 1949 and participated in this competition for territorial recovery, it found that major land territories in the scs had already been occupied by the other States concerned, and so it felt that it was destined to assert an ideological or historic sovereignty over its intrinsic territory by the use of China's traditional 'Ninedash-line' claims as the successor State of China, a modified version of the similar 'Eleven-dash-line' claims made by the former Government, and the PRC has continually made an attempt to effectively control the rest of mostly untouched features such as low tide elevations, underwater shallow reef (or shoal) through dredging and reclamation, and it has actually occupied some features in the Paracel Islands and the Spratly Islands by the use of force in 1979 and 1988, although, as a matter of principle, it is impossible in law to appropriate or incorporate underwater maritime features (except for islands or high-tide rocks).

It is true that, from the 18th century to the 19th century, hăinán fishermen engaged in traditional fisheries in the adjacent waters of the Spratly Islands and left a series of log books (entitled gēnglùbù) registering sea routes and fisheries, which the Arbitral Tribunal considered as evidence for the Chinese fishermen's traditional but non-exclusive right in the territorial waters of a rock, while the Tribunal recognized the similar traditional non-exclusive rights of the Filipino fishermen and others as well.

It appears that, in its history, China has made a vague distinction between the coastal sea and the offshore sea, but their scope and demarcation were not clear. In the 1930s, the Republic of China issued a decree on three-mile territorial sea. It is said that a U-shaped lines had appeared in a non-official map around 1933. After the Second World War, in 1948, the Ministry of Interior of the Republic of China published the 'Eleven-dash-line' map produced

7 The Cairo Declaration, 27 November 1943, Department of State [USA], The Department of State Bulletin, No.232, at 393. 1 Japan's Foreign Relations-Basic Documents $55^{-56}$. 
in December 1947. This was the direct origin of the 'nine-dash-line' map and claims for islands as well as related waters. After that, in 1949 the PRC Government was established, and it adopted that map and claims, and since 1953 two dash-lines were deleted in the Gulf of Tonkin (Dōngjīng Wān), or Northern Gulf (Běibù Wān). ${ }^{8}$

In 1958 the PRC made a declaration on 12-mile territorial sea, allowing for straight lines between the mainland and the coastal islands and requiring not only foreign airplanes but also foreign military vessels to procure the permission from the Chinese authorities for their passage through the territorial waters. While it was stipulated that these rules also apply in the Spratly Islands, it was unknown whether they meant to apply the straight baselines or to require foreign military vessels to seek and get passage permits from the authorities. In 1992 the PRC enacted the Law on Territorial Sea and Contiguous Zone, which formally introduced 12-mile territorial sea and straight baselines without any geomorphological restriction, and it clarified that China's territory includes the Spratly Islands, the Paracel Islands and the Pratas Islands in the scs. ${ }^{9}$ In 1996 it issued a Declaration on Territorial Sea Baselines, and in the same year the PRC ratified the UN Convention on the Law of the Sea (UNCLOS), and it issued a Declaration on Exclusive Economic Zone (EEZ) but therein did not mention any historic right yet. Then, in 1998 it enacted the EEz law, in Article 14 of which, for the first time, the preservation of a historic right was mentioned as 'the rights that the People's Republic of China has been enjoying ever since the days of the past'. ${ }^{10}$ However, it was in 2009 that the PRC officially gave an international law formula to the so-called 'Nine-dash-line' claims.

In that year, Malaysia and Vietnam jointly submitted to the Commission on the Limits of the Continental Shelf (the CLCS) an application for extending the continental shelf over 200 miles, and in the notes verbales conveyed to the UN Secretary-General in response to this joint submission, China stated as follows:

China has indisputable sovereignty over the islands in the South China Sea and the adjacent waters, and enjoys sovereign rights and jurisdiction

For the recent deals, see Coalter G. Lathrop, International Maritime BoundARIES, Volume VII, Report No.5-25 (Add.1), (2016) 4842-4846.

9 As well as the Pinnacle Islands (Diàoyúdăo; Senkaku) in the East China Sea.

10 In the Matter of the South China Sea Arbitration (Philippines v. PRC), An Arbitral Tribunal Constituted under Annex VII to the 1982 un Convention on the Law of the Sea, Award of 12 July 2016 para. para.179, PCA Case No.2013-19 (Registry: Permanent Court of Arbitration), https://pcacases.com/web/sendAttach/2086 [hereinafter Tribunal's Award (merits)]. 
over the relevant waters as well as the seabed and subsoil thereof (see attached map). The above position is consistently held by the Chinese Government, and is widely known by the international community. ${ }^{11}$

It is to be noted that the Arbitral Tribunal regards this statement as a definitive answer to the question of the 'Nine-dash-line' claims. And a well-known map depicting the 'nine-dash-line' was appended to those, the PRC's notes verbales. Malaysia and Vietnam as well as the Philippines lodged their protests against the statement. And, in its rebuttal to these protests, the PRC repeated the same statement as above (regarding a series of log books entitled gēnglùbù registering sea routes and fisheries) and said that 'China's sovereignty and related rights and jurisdiction in the South China Sea are supported by abundant historical and legal evidence.' What it mentioned as such evidence, however, is the publicised geographical scope and Chinese names of the maritime features in the SCs; the 'relevant provisions of the 1982 UNCLOS' as well as the domestic laws of the PRC on the Territorial Sea and Contiguous Zone (1992) and on the EEZ and the Continental Shelf (1998), under which the PRC asserted that 'China's Nansha Islands (Spratly Islands) is (sic) fully entitled to Territorial Sea, Exclusive Economic Zone (EEz) and Continental Shelf.'12 In China's formal statement released after the Tribunal's Award on Jurisdiction (29 October 2015), it was said that 'China's sovereignty and relevant rights in the South China Sea' had been 'formed in the long historical course', and that they were reaffirmed by China's domestic laws and 'protected under international law including the UN Convention on the Law of the Sea' [emphasis added]. ${ }^{13}$

\section{II \\ The Arbitral Tribunal's Characterisation of the 'Nine-Dash-Line' \\ Claims: (I) Historic Sovereignty, (Ii) Historic Waters, And (Iii) Historic Rights, and the Tribunal's Definitive Reasoning}

Partly in accordance with the Philippines' quite sophisticated submissions and partly relying on its own former jurisprudence ${ }^{14}$ the Arbitral Tribunal has, in

\footnotetext{
11 Notes verbales from the Permanent Mission of the PRC to the UN to the Secretary-General of the UN, no.CML/17/2009 (7 May 2009); no.CML/18/2009 (7 May 2009).

12 Tribunal's Award (merits) para. 185.

13 Ministry of Foreign Affairs, PRC, Statement of 30 October 2015. Tribunal's Award (merits) para. 187 .

14 In the Matter of the Chagos Maritime Protected Area Arbitration the majority of the Tribunal considered that, so long as the core of a submission by the plaintiff is not primarily
} 
the preliminary phase, already concluded that the question of existence or source of entitlements has no direct relevance with the question of sovereignty over the islands or rocks in the scs, and that it has no direct relevance to the delimitation of the maritime zones, either. The question of delimitation would not occur unless there is any overlapped area to which the Parties have laid claim. So, the Tribunal has, in principle, considered that it has jurisdiction over the issue of the 'Nine-dash-line' claims in general terms. Besides that, the reason the Tribunal decided to judge on the claims, combining the question of jurisdiction with the merits of the case, is that the Tribunal considered it necessary to characterise what the PRC claimed as 'the [historic] rights that the People's Republic of China has been enjoying ever since the days of the past' (1998) or what it claimed as sovereign rights or jurisdiction in the official statement on the 'Nine-dash-line' claims, i.e. the notes verbales to the UN Secretary-General (2009). That is because the Tribunal considered that the final judgment on jurisdiction depends on (a) the nature of the 'historic rights' the PRC claimed and (b) whether those 'historic rights' fall under the matters of 'historic bay or titles' excluded from the Tribunal's jurisdiction (Article 298, UNCLOS).

The Arbitral Tribunal, as mentioned above, noted China's formula in law for the 'Nine-dash-line' claims in the 2009 notes verbales. The formula in the PRC's statements consists of two parts: the former part of the sentence 'indisputable sovereignty over the islands in the South China Sea and the adjacent waters', which corresponds to the assertion for sovereignty itself (dominium) over the landmass of the maritime features and their territorial waters; and the latter part of the sentence 'sovereign rights and jurisdiction over the relevant waters as well as the seabed and subsoil thereof , which correspond to historic rights (imperium) for preferential treatment similar to the EEZ/continental shelf in the maritime area within the 'nine-dash-line' but beyond the entitlements or

aimed at the argument of sovereignty over disputed islands, although the dispute itself involves some sovereignty matters but only supplementarily, the legal issue, in its core, amounts to the interpretation of the UNCLOS (evaluating where the relative weight of the dispute lies). The Chagos Marine Protected Area Arbitration (Mauritius v. UK), Award of 18 March 2015, An Arbitral Tribunal Constituted under Annex VII of the UN Convention on the Law of the Sea,. paras. 211-212, PCA Case No.2011-03 (Registry: Permanent Court of Arbitration), available at: http://www.pcacases.com/pcadocs/MU-UK\%2020150318\%20 Award.pdf.

For whether or not the UK is the 'coastal State' concerned, see also the Dissenting and Concurring Opinion by Judges J. Kateka and R. Wolfrum (18 March 2015) paras. 3-17, available at: https://pcacases.com/web/sendAttach/1570. 
the scope of the UNCLOS. It is prima facie not known whether this formula also means to indicate the assertion for historic titles to waters, which would make the whole maritime area within the 'nine-dash-line' integral part of China's internal waters or pseudo-archipelagic waters (although this kind of adamant assertion is repugnant to the UNCLOS).

The Philippines made against it the submissions (a) that the rights which the PRC has asserted beyond those recognized under the UNCLOS have all been relinquished and disappeared by China's accession to the UNCLOS (i.e. in the Filipino view, territorial waters around the high-tide maritime features are only acceptable.); and (b) that such historic rights claimed by the PRC have never been established.

Judging from China's statements, conduct and State practice, ${ }^{15}$ the Tribunal eventually characterised one aspect of China's 'Nine-dash-line' claims as claims formed in the long, historical process, namely its sovereign rights or jurisdiction far beyond the adjacent water of the maritime features within the 'nine-dash-line', which would be beyond the entitlements to territorial waters, EEZs or continental shelves normally recognized under the UNCLOS.

Accordingly, the Arbitral Tribunal limited its scope of examination to one aspect of the 'Nine-dash-line' claims related to the 'historic rights to the living resources and non-living resources', the legal basis of which is not the UNCLOS but 'a constellation of historic rights' that do not amount to the title to the related waters. ${ }^{16}$ And the Tribunal interpreted the relevant articles of the UNCLOS and concluded that (i) the UNCLOS, in particular the articles for the EEZ regime, neither preserve nor protect such rights to the living or non-living resources as established by a unilateral act, independently of the UNCLOS, while such rights within the territorial waters might be taken for consideration [the Tribunal's definitive reasoning]; (ii) in addition, if that is not the case, China's asserted historic rights have never fulfilled any of three requirements in law for them: (a) actual exercise of authority in the waters concerned; (b) the continuity of the exercise of authority; and (c) other States'

\footnotetext{
15 e.g. The Tribunal referred to the China's bit to unilaterally establish zones for exploiting the seabed oil resources near the Vietnamese coast far beyond over 200 miles from its claimed islets in the Spratly Islands; the exchange of objections between the PRC and the Philippines regarding the act of obstructing the Filipino research activities for gas and oil in sunken Reed Bank; the PRC's 2012 decree forbidding the fisheries all over the Spratly Islands in a season of summer; and China's policing activity in the area of Scarborough Shoal on the basis of that decree.

Tribunal's Award (merits) para. 229.
} 
attitude such as recognition, acquiescence or the historic consolidation of a title, etc. ${ }^{17}$

The PRC neither had nor exercised such historic rights or jurisdiction as a State for the period of years until the UNCLOS was made into force. As per the Chinese traditional fisheries within the territorial waters of the maritime features like rocks, it is true, the Chinese fishermen enjoyed such fisheries but they were not of exclusive nature, and the Filipino and other countries' traditional fisheries coexisted with the Chinese. And the Chinese authorities in any period of time had never provided fishery permits for those fishermen. Furthermore, as per the asserted jurisdiction on the seabed oil or gas fields, the PRC has just recently claimed them after it ratified the UNCLOS, and so it is unacceptable. In the Tribunal's view, it is considered that, by acceding to the Convention in 1996, the PRC renounced or relinquished the assertion for such rights remaining in other States' EEZs, newly allocated under the UNCLOS; and (iii) after its entry into the UNCLOS, the PRC mentioned its preserved historic rights in a vague manner, but other States could not judge on the nature and scope of such rights for considering whether they should raise objections to them. This does not amount to any acquiescence on the part of other Parties. On the other hand, there is no doubt that the PRC's assertions in law which have been developed since 2009 met the other Parties' diplomatic protests. Consequently, the Tribunal did not consider that such rights had any way been established, after or since the UNCLOS came into force. They are repugnant to the EEZ/continental shelf regimes under the Convention.

By acceding to the UNCLOS, in the Tribunal's view, the PRC did not make its historic rights relinquished, but rather it gave up the rights enjoyed under the freedom of sea in the high seas area which was newly allocated to other States' EEzs by the international community. ${ }^{18}$

After all, the Tribunal admitted the submissions made by the Philippines regarding the unlawfulness of China's 'Nine-dash-line' claims. It considered that the legal issue in the Philippines' assertion is concerned only with one of the 'Nine-dash-line' claims related to the maritime rights and entitlements in the scs; the scope of such entitlements is not allowed to be beyond that allocated by the UNCLOS; the historic rights, or other sovereign rights or jurisdiction, which the PRC claimed, has no legal effect, as far as they are, in geographical

17 UN, Juridical Regime of Historic Waters, including Historic Bays, UN Doc.A/CN.4/143, para.185 (9 March 1962). 
or substantive limit, beyond the entitlements under the UNCLOS; and any of China's historic rights, sovereign rights or jurisdiction, beyond the Convention's limit is regarded as relinquished. ${ }^{19}$

\section{The Evaluation of the 'Nine-Dash-Line' Claims}

By way of a conclusion, the Arbitral Tribunal characterised the meanings of the 'nine-dash-line' under international law. Leaving aside the relevance to the naval command or national security, China asserted 'nine-dash-line' as the demarcation line of its maritime zone under its jurisdiction based on the historic rights. However, that is not historic waters, i.e. neither internal waters nor archipelagic waters.

It is to be noted that the substantive claims consist of several legal issues (i) firstly, asserting the sovereignty over the land territory and territorial waters within the nine-dash-line with a full-fledged jurisdiction (just like Japan's claims for New Southern Islands were so intended in 1939); (ii) secondly, asserting sovereign rights and jurisdiction over the relevant waters as well as the seabed and subsoil thereof within the nine-dash-line; but (iii) thirdly, allowing all foreign States to enjoy freedoms of overflight, navigation and laying the submarine cables and pipelines; (iv) fourth, asserting the competence to authorise foreign and domestic companies to engage in exploring and exploiting the living and non-living resources within the nine-dash-line in the SCs; (v) fifth, the traditional maritime borders are demarcated by the 'nine-dashline' as between the PRC and ASEAN coastal countries (although the more practical lines are sine qua non for practical negotiations); (vi) sixth, the status or entitlements of islands, seabed or upper waters thereof should be interpreted in accordance with the sovereign rights and jurisdiction in the territorial waters, EEZ and continental shelf regimes under the UNCLOS; however, (vii) lastly, the rules of distance on 200-mile EEzs/continental shelves or outer continental shelves beyond 200 miles under the UNCLOS do not apply. ${ }^{20}$

\footnotetext{
19 Tribunal's Award (merits) para. 278.

2 Cf. Yasuyuki Yoshida, minami shina kai ni okeru chugoku no "kyudansen" to kokusaiho [China's "nine-dash-line" in the scs and international law], 5-1 kaijo jieitai kanbu gakko senryaku kenkyu [Strategic Studies, Maritime Self-defense Forces Senior Officers College] 9 (June 2015); Agora: The South China Sea, 107 American Journal of International LAW 95 et seq. (2013); D.R. Rothwell, et AL, (eds.) The OXford Handbook of the LAW OF THE SEA 629-630 (2015).
} 
It appears that the PRC still has some alternative courses of action available. The first alternative in law might be to retreat simply into the prototype of the 'New Southern Islands', a pre-war position asserting the sovereignty over the maritime features above water only, on the basis of historic title or occupation, whereas I know the PRC leadership could not follow it in terms of its domestic politics. In any case, the Tribunal's Award preserves this aspect of the 'Ninedash -line' claims. The Tribunal stated as follows: 'because the Tribunal considers the question of historic rights with respect to maritime areas to be entirely distinct from that of historic rights to land, the Tribunal considers it opportune to note that certain claims remain unaffected by this decision.21 ${ }^{21}$ emphasis added] As far as the sovereignty over the landmass above water is concerned, there is a possibility for the PRC to contend for the occupation of part of territory in the scs, invoking historical records of actual control or acquiescence on the part of other States (for instance, by historical consolidation of a title). ${ }^{22}$ As far as the military or policing activities by the naval forces are concerned, they are outside of the Tribunal's jurisdiction (Article $289 \mathrm{l}(\mathrm{b})$ ).

The second alternative might be to denounce the UNCLOS straightforwardly by notifying its withdrawal from the Convention itself, invoking Article 317 of the UNCLOS, although such withdrawal does not affect the binding force of the scs Award itself. However, should it follow this alternative course, the PRC would only stand in the same position as that the United States has held ever since the UNCLOS came into force. The Us is still outside of the UNCLOS, holding a virtually free hand in the Pacific without any possibility of being sued in unilateral legal action. In the United States practice, in fact, the us Government also has established a 200-mile EEZ extending from the baseline of both 'Johnston Atoll' with no inhabitant, hundreds miles southwest from the Hawaii Islands and 'Kingman Atoll' in the American Samoa. ${ }^{23}$

\footnotetext{
21 Tribunal's Award (merits), para. 272.

22 Z. Gao and B.B. Jia, The Nine-Dash-Line in the South China Sea: History, Status and Implications, 107 American Journal of International LaW 98-123 (2013).

23 The Ministry of Foreign Affairs (MOFA), Japan, also follows the us practice despite the fact that Japan is a party to the UNCLOS, unlike the Us. In the case of a rock in the offshore sea like the Pacific Ocean, the issue is related to whether the 200-mile continental shelf concerned or any outer continental shelf beyond 200 miles affects the Common Heritage of Mankind or the object and purpose of the Deep Seabed regime. Japan still relies on a dubious position in law concerning Douglas Atoll (Okinotorishima). Infra note 59, $c f$. Tribunal's Award (merits) para. 623 .
} 
For example, the PRC might evade the very restrictive tests of an island and rocks which could have their own EEzs and continental shelves (which would be completely limited to a small number of rocks being capable of sustaining a 'local community of people and livelihood of coastal fishermen and ethnic inhabitants in their natural conditions' ${ }^{24}$ ), if it were outside of the Convention. In other words, only if it would manage to withdraw from the UNCLOS in the future, the PRC might, as a matter of policy, continue asserting that every rock above the water not only has territorial waters but also is entitled to both an EEZ and a continental shelf in the SCS (as a whole), irrespective of brand new tests on the maritime features in question devised by the Tribunal. ${ }^{25}$

Presumably the third and practical alternative for the PRC and ASEAN coastal States would be to open 'parliamentary' negotiations, including bilateral ones, again and seek a compromise agreement among them for the purpose of establishing a 'new local maritime regime'. Article 311, paragraph 3, provides that the Parties, as between them, may conclude agreements modifying or suspending the operation of the UNCLOS, provided that those agreements not affect the object and purpose of the Convention or other Parties' rights and obligations. Accordingly, only if the PRC and other States concerned in the South China Sea would succeed in working out such agreements, then those States, including the PRC, might be capable of applying some exceptional straight baselines for their territorial waters between high-tide features and low-tide elevations without objections. ${ }^{26}$ Or, that compromise may be based on a totally innovative measure like a basic treaty on the complete freezing or moratorium of further territorial claims with the establishment of a provisional common

24 This is a test, quite novel to not a few lawyers, devised by this Award for sustaining the object and purpose of the EEZ regime: i.e. supporting the livelihood of coastal fishermen and ethnic inhabitants.

25 Infra Section 5 .

26 The Tribunal, however, indicated that the use of such a straight baseline might be repugnant to the UNCLOS with respect to an offshore archipelago. Tribunal's Award (merits) paras. 573,575 , and 576 . Nevertheless, such State practice has been partly witnessed, in spite of the Tribunal's interpretation of Articles 7 and 47. See, e.g. too freely drawn straight baselines of Myanmar's more than 222-mile long line across the Gulf of Martaban, Vietnam's more than 161-mile long line between its islets, and Japan's straight baselines off the North-Western coast of Shimane and Yamaguchi Prefectures, Chugoku Region. Y. Tanaka, The International LaW of the Sea (2012) 49; A.V. Lowe and R.R. Churchill, The Law of the Sea (1999) 57. Apart from its 'Nine-dash-line' claims, it is to be noted that China is not clearly claiming an EEZ or continental shelf from any of these particular maritime features in question, just as the other claimants like Philippines, Malaysia and Vietnam have not done so. 
zone for sharing resources, like a draft treaty on the Spratly Islands proposed by M.J. Valencia in 1992 Jogjakarta unofficial consultation. ${ }^{27}$ Mr Rodrigo Duterte, new President of the Philippines, appears to have intended to put it behind the Parties after the Award was delivered and 'is moving toward a more neutral stance.'28 However, a mere pandering to a modus vivendi on rules of conduct such as the lowest common denominator amongst the States concerned would no way help.

\section{The Arbitral Tribunal's Tests of an Island and Rocks ${ }^{29}$}

When it comes to the Award's impact on the UNCLOS and the law of the sea regime, it is to be noted that in that Award the Arbitral Tribunal has elaborated thoroughly the definition of an island and rocks and adopted a correlative interpretation of Article 121 regarding the regime of islands as a whole. In its operative conclusions the Tribunal stated that all the maritime features in the scs are rocks or low-tide elevations, indicating that there is no islands in law and, on the basis of assistance by specialists or experts of oceanographic geomorphology or geology, recognizing six features as rocks and four as lowtide elevations amongst the maritime features of which the Philippines has made an issue. Moreover, the Tribunal discussed the status of the largest island in the scs, i.e. 'Tàipíng Dăo' or 'Itu Aba Island', in the course of reasoning, enquiring whether it could be entitled to have an EEZ or continental shelf. That is because it is unavoidable for the Tribunal to do so in order to ascertain whether they were part of EEZs to be delimited from the mainland of the Philippines (Palawan Island); and whether the Tribunal would be entitled to have competence or admissibility for deliberation on the jurisdiction issue. If

27 M.J. Valencia, J.M. Van Dyke and N.A. Ludwig, Sharing the Resources of the South China Sea, (1997) Chapter 3.

28 Mark J. Valencia, Perilous South China Sea plan, JAPAN Times, 18 January 2017 (This piece first appeared in the ipp Review).

29 As regards Article 121 (3), see D.R. Rothwell, et Al. eds., The Oxford Handbook OF the LAW OF The SEA (2015) 262-263, 272-274; Yoshifumi TANAKa, The International LaW of the Sea (2012) 64-68, 402; D. Freesone, et AL., eds.The LaW of THE SEA (2016) 89-9o; Sookyeon Huh, kokusaiho jo no shima no teigi to kokunaiho seido [the definition of an island and domestic law regime], 19 ronkyu jurisuto [Exhaustive Discussion, Jurists] 14 (autumn 2016, yuhikaku); Naoki Iwatsuki, minami shinakai chusai saiban to kokusai funso no heiwateki kaiketsu [the scs arbitration and the peaceful settlement of an international dispute], 435 hogaku kyoshitsu [Jurisprudence Classroom] 48, 52-54 (December 2016, yuhikaku); D.R. Rothwell and Tim Stephens, The InterNational LaW OF THE SEA (2016) 89-90. 
the defendant State has made such a declaration for exception as the PRC did, the UNCLOS does not allow arbitral tribunals to deal with disputes concerning the delimitation of the overlapping EEzs or continental shelves between States with opposite coasts.

As per the regime of islands and rocks, Article 121 states as follows:

1. An island is a naturally formed area of land, surrounded by water, which is above water at high tide.

2. Except as provided for in paragraph 3, the territorial sea, the contiguous zone, the exclusive economic zone and the continental shelf of an island are determined in accordance with the provisions of this Convention applicable to other land territory.

3. Rocks which cannot sustain human habitation or economic life of their own shall have no exclusive economic zone or continental shelf. [emphasis added]

The Tribunal considers that, so far as the maritime features concerned indicate no 'capacities' of their own in the natural conditions, they have no relevance even if there was real habitation or economic life in the certain period of time. And the wording of 'sustain' means the elements of time and quality. It matters whether there is a certain length of time for habitation and what the yardstick for its quality is. Furthermore, the Tribunal considers that the maritime features have entitlements to the EEZ and continental shelf, either if it is possible to dwell on or if there exists the economic life of their own by the local community of people. That is because, given the object and purpose of the regime, it is understood that such entitlements to those maritime zones ought to help and ensure that such communities could be sustained or developed. It does not matter if only a few families settled there, so far as they are not intentionally settled by the outer authorities. They may move from the adjacent islands to live and lead an ordinary life on the features concerned. However, the Tribunal further goes on to restrict the conditions. It considers that, although it is difficult to draw a distinction between economic 'life' and economic 'activities', the wording of 'life of their own' is very important, and that the activities such as (a) those based on the resources from the outside completely; (b) those making use of the features as the object of 'extractive activity' only, without any participation by the local people; and (c) those using the adjacent waters only, like fisheries conducted by the companies from the outside, do not fall within the realm of 'economic life of their own' ${ }^{30}$ In passing, the Tribunal classified the maritime features into (a) islands [landmass] and rocks [rocks 
above water], (b) low-tide elevations, rocks, sandbanks and sandbars, (c) underwater features (underwater shoals, reefs, banks, sunken rocks, submarine elevations). ${ }^{31}$ The status of rocks may vary with the methods of measurement and topographical survey either in accordance with the average tide level or the lowest tide level during years.

In the course of preparatory works of the UNCLOS, it was pointed out by Singapore that it would be necessary to restrict the scope of EEzs somehow so that they might encroach the new regime of Deep Seabed based on the idea of common heritage of mankind, while France was all against it and Mexico proposed for an exception on the basis of equitable principles. However, this issue was moved to deliberation by the unofficial committee, which finally produced a draft article leading to the present Article 121. Then, Japan, Greece and the UK still resisted with attempts to remove Paragraph 3, but the draft was at last adopted as consensus after much complicated negotiation. It was a result of package deal for ensuring EEzs interests on the part of coastal people and the preservation of the common heritage of mankind. ${ }^{32}$

The Tribunal has drew attention to the facts that (a) Article 121, para.3, is a restrictive clause; (b) in the course of negotiations it was discussed with reference to other aspects or questions of the UNCLOS, such as ensuring the interests of people of the coastal States, the question of an island under foreign control or colonial governments, the introduction of the Deep Seabed regime and the idea of common heritage of mankind, the protection of interests of archipelagic States, the role of an island in the maritime delimitation, residual concerns about the possibility of an artificial structures generating maritime zones, etc.; (c) the diversity of maritime features unfortunately makes a unitary, clear test unacceptable. ${ }^{33}$ In particular, such diversity makes it of no practical use to draw a distinction by yardsticks concerning size and gross area, so long as there is, on one hand, a vast, large uninhabited island or there is, on the other hand, a tiny island where the population leads a normal life, depending on the maritime resources. ${ }^{34}$ The Tribunal considers that, although the size of a maritime feature has correlation with the availability of food, water, space for living and resources for economic life, the size for itself is not conclusive with respect to determination on the status of the maritime feature, whether it is an island or a rock. The size of a feature has no important relevance in law. ${ }^{35}$

\footnotetext{
31 Tribunal's Award (merits) para.507.

32 Tribunal's Award (merits) paras.529-533.

33 Tribunal's Award (merits) paras. 536-537.

34 Tribunal's Award (merits) para. 538.

35 Territorial and Maritime Dispute (Nicaragua v. Colombia), Judgment, 2012 I.C.J. 624, para. 37 (19 November).
} 
Interpreting Article 121, paragraph 3, the Tribunal, by way of a conclusion, stated as follows:

(i) 'rocks' are not limited to solid rocks in geology or geomorphology.

(ii) The status of rocks is determined on the basis of their 'natural capacity'.

(iii) 'human habitation' must not be a temporary dwelling but must be said to constitute the natural population of the maritime feature. In brief, it must be able to sustain a 'stable community of people' who can remain there and consider it as their home. Such a community does not necessarily need to be large, and in the case of remote, offshore atolls, a small number of people ('a few individuals and family groups') may well suffice. Migrating nomadic people's periodic, habitual residence falls within the realm of 'human habitation'. That includes the dwelling and livelihoods of not only indigenous people in the sense of anthropology but also non-indigenous people, so long as the latter really intend to reside in and make their lives on the features.

(iv) 'Economic life of their own' is closely related to the requirement of human habitation, but it does not mean economic value the maritime feature contains. It means sustaining economic life. It normally means that people make their home, lead everyday life and livelihoods there on the island or group of islands, or on maritime feature or features. The wording of economic life 'of their own' means such a life oriented to the maritime feature or its adjacent zones around it. It does not mean such economic life as oriented exclusively to the waters or seabed of the surrounding territorial sea. It does not mean activities such as (a) those entirely dependent on the external resources completely; (b) those making use of the features as an object for 'extractive activities' only, without any participation or involvement of local people; and (c) it is rational to consider that, although extractive economic activity to harvest the natural resources of an island or rocks (in particular, by the companies for the benefit of stakeholders elsewhere) might be the development or exploitation of resources for gaining economic profit but would not reasonably constitute the economic life 'of their own'.

(v) 'human habitation' under Article 121, paragraph 3, is one thing, and 'economic life of their own' another. They are to be disjunctively read. Indeed, high-tide features which could sustain either of them may have entitlements to the EEZ and continental shelf. However, as a practical matter, such features where a stable community of people inhabits will ordinarily be able to sustain economic life of their own. 
There will be one exception where there are people sustaining themselves through a network of related islands and rocks. In that case, the existence of human habitation would not be denied even if they do not dwell on a single island. Similarly, even in the case that local people's economic life or livelihood straddles a number of islands, the element of human habitation or economic life of their own will not be denied.

(vi) Article 121, paragraph 3, concerns the 'capacity' of maritime features to sustain human habitation or economic life of their own. ${ }^{36}$ So, it does not necessarily mean that people do live at the moment, have lived ever since or once lived there, or that they do lead at the moment, have led ever since or once led economic life. The 'capacity' itself is the objective test. And the issue of sovereignty with respect to the maritime features has no relevance. Accordingly, the Tribunal considers that it would not be precluded from evaluating the maritime features concerned.

(vii) The capacity of a feature must be assessed on a case-by-case basis. The Tribunal considers that it would be possible to identify the principal factors for the 'natural capacity' of a feature: i.e. the presence of (a) water, (b) food and (c) shelter in sufficient quantities. Moreover, such factors also include (d) the prevailing climate, (e) the proximity of the feature to other inhabited areas and populations, and (f) the potential for livelihoods on and around the feature. Although minute, barren features may be obviously uninhabitable and large, heavily populated features obviously capable of sustaining human habitation, the Tribunal considers, an abstract test of the objective requirements for human habitation or economic life could or should not be formulated. On the other hand, it is true that human habitation must entail more than the mere survival of humans on a feature, while economic life must entail more than the presence of resources.

(viii) The capacity of a feature should be assessed with due regard to the potential for a group of small island features. The requirement for human habitation or economic life in Article 121, paragraph 3, excludes a dependence on external supply. Likewise, (a) economic activity that remains entirely dependent on external resources or (b) economic activity that makes use of a feature as an object for extractive activities, without the involvement of local people does not constitute economic life 'of their own'. However, it is comprehensible that remote island 
populations often make use of a number of islands, spread over significant distances, for sustenance and livelihoods. The Tribunal does not equate the role of multiple islands as a network with the continued supplies from outside, provided that such islands collectively form part of a network of islands. Likewise, it does not equate the local use of nearby resources as part of the livelihood of the community with the use by distant economic interests aimed at extracting natural resources. ${ }^{37}$

(ix) By way of a conclusion on the interpretation of Article 121, paragraph 3, evidence of the objective, physical conditions on a particular feature could be guidelines for classification. In particular, evidence of physical conditions will ordinarily suffice to classify features into one category or the other. If a feature is (a) entirely barren of vegetation and (b) lacks drinkable water and (c) the foodstuffs necessary even for basic survival, it lacks the capacity to sustain human habitation. The opposite conclusion will be reached where the physical size of a large feature makes it definitively habitable. The evidence of physical conditions, nevertheless, is insufficient in borderline cases of features. It is difficult to determine, from the physical characteristics of a feature alone, where the capacity merely to keep people alive ends and the capacity to sustain habitation by a human community begins. The threshold may differ from one feature to another. ${ }^{38}$

(x) In such circumstances, the most reliable evidence of the capacity of a feature will be the evidence of the 'historical use'. If the historical record of a feature indicates that nothing resembling a stable community of people has ever developed there, the reasonable conclusion would be that the natural conditions are too difficult for such a community to form and that the feature is not capable of sustaining human habitation. In such circumstances, however, it is to be ascertained whether human habitation has been prevented by natural or artificial forces from outside that are separate from the intrinsic capacity of the feature, such as war, pollution, environmental destruction or harm, etc., which could lead to the depopulation of a feature, although it is capable of sustaining human habitation in its natural state. In the absence of such natural or artificial intervening forces, however, a feature that has never historically sustained a human community lacks the capacity to sustain human habitation. ${ }^{39}$ 
(xi) Conversely, if a feature is inhabited or has historically been inhabited, it is to be ascertained whether there is evidence to indicate that habitation was only possible through outside support. So far as they are conducted to improve the quality of life of its inhabitants, trade and links with the outside world do not disqualify the status of a feature or its entitlements to maritime zones. However, where outside support is so important that it constitutes a necessary condition for the inhabitation of a feature, then it is no longer the feature itself that sustains human habitation. In this respect, a purely official or military population, serviced form the outside, does not constitute evidence for human habitation. It is to be noted that the purpose of Article 121, paragraph 3 , is to place limits on excessive and unfair claims by States. That purpose would be undermined if people were sent on to an inhabitable feature in order to stake a claim to the territory and the maritime zones. Consequently, historical evidence of human habitation that existed before the creation of EEZs may be more significant than contemporary evidence, if the latter is motivated by no more than an apparent attempt to claim maritime zones. ${ }^{40}$

(xii) The same method of analysis would apply likewise to the past or current existence of economic life. With respect to economic life, in the first place, it is necessary to consider evidence of the use of a feature in historical record, and then go on to consider whether that historical record does not fully reflect the economic life the feature could have sustained in its natural condition. ${ }^{41}$

On the basis of the jurisprudence of the ICJ and other cases, the Tribunal concludes that there is no evidence for an agreement based on subsequent State practice (in the sense of Article 31, paragraph 3, of the 1969 Vienna Convention on the Law of Treaties) on the interpretation of Article 121, paragraph 3, which differs from the Tribunal's above interpretation. ${ }^{42}$

As the preceding summary of the Tribunal's interpretation shows, apparently, the new, restrictive definition of a feature which would be entitled to have the EEZ and continental shelf does not draw a distinction between an island and rocks, and it might undermine stability in law in that it would disqualify still not a few maritime States' practice that has unilaterally established not only territorial waters but also other maritime zones around uninhabitable rocks. It might also undermine an ordinary perception about the idea of

\footnotetext{
40 Tribunal's Award (merits) para. $55^{\circ}$.

41 Tribunal's Award (merits) para. 551.

42 Tribunal's Award (merits) paras. $55^{2-553}$.
} 
an island on the part of the general public. The Tribunal interprets 'human habitation' as constituting a 'stable community of people' on a feature in the anthropological or sociological sense of the word. Moreover, in this respect, it considers that it is necessary to see not factual habitation but the capacity of a feature in its natural conditions, regardless of basic, technological development, such as an underground water dam system. ${ }^{43}$ It also considers that the Tribunal could assess such capacity of a feature in its natural state on a case-by-case basis, with the assistance or advice from specialists or experts. It remains to be seen whether this could ever become a practical and equitable test.

In any case, the Tribunal invoked this test comprehensively in assessing not only the maritime features which the Philippines requested the Tribunal to assess but also Itu Aba Island (at the present moment Taiwan's 'Tàipíng Dăo') and other features in the SCS, and it concluded that all the maritime features in the scs, including Itu Aba Island, are 'rocks' or low-tide elevations which have no entitlements to the EEZ or continental shelf of their own. And, because, without such judgement, the proceedings would have become a dispute on the maritime delimitation of overlapping Eezs between States with opposite coasts, the Tribunal could not have had jurisdiction over this case in accordance with Article 298 (a), UnCLOS. Likewise, the Tribunal in the merits, too, invoking the same reasoning, concluded that Mischief Reef and Second Thomas Shoal are not even 'rocks' but low-tide elevations, and that they are part of the 200-mile EEZ delimited from the mainland Philippines (Palawan Island). However, so long as the PRC, the absent defendant Party to the case, might keep the position that even rocks can have EEZs, it might have been necessary to ascertain exactly what position it keeps.

The Tribunal's Award did not discuss how to distinguish the 1993 case on maritime boundary in the area between Greenland and Jan Mayen, in which the International Court of Justice recognized that Jan Mayen Island (Norway) could have 200-mile fisheries zone in accordance with the former regime of the law of the sea, although it was a rock whose population only constituted governmental officials. Moreover, although the legal issue concerned delimitation on the maritime zones, the Tribunal did not in detail discuss the 2009 case

43 An underground water dam system has traditionally been built for islanders' habitation and economic life of agriculture, for example it is to be seen in Fukusato, Miyako Jima Island, one of the southernmost Ryukyo Islets of Japan, which sustains a population of over 54,00o. miyako jima ni okeru chikadamu kaihatsu chosa no gaiyo [The general outlines of the research and development of underground dams in Miyako Jima Island] (Japan's Ministry of Agriculture and Fisheries, October, 1981). 
on the Black Sea maritime delimitation, ${ }^{44}$ in which the International Court of Justice (ICJ) dealt with the role of Serpents' Island, an uninhabited Ukrainian island in the Black Sea off the borders between Rumania and Ukraine, and the ICJ was faced with the interpretation of Article 121, paragraph 3. It does not appear that the Tribunal in the sCs judgement elaborated sufficient reasoning for relying on or distinguishing from it, nor that it indicated sufficient correlation with the former principal jurisprudence. In the Black Sea delimitation case, although the ICJ intentionally avoided a direct interpretation of Article 121, paragraph 3, it only took into consideration the territorial sea around Serpents' Island in delimitation, ignoring Ukraine's claim for the EEZ of the Island itself by enclaving it. That corresponds with the consequences of the sCs Award. ${ }^{45}$

Amongst the dispositive conclusions of the Award, there is statements that 'none of high-tide features in the Spratly Islands, in their natural condition, are capable of sustaining human habitation or economic life of their own', and that 'none of the high-tide features in the Spratly Islands generate entitlements to an exclusive economic zone or continental shelf.' ${ }^{\prime 6}$ In the body of the Award, the Tribunal discussed the status of Itu Aba Island. ${ }^{47}$ However, these might be a logical consequence of ratio decidendi for the Tribunal's jurisdiction or admissibility, not ratio decidendi for the Tribunal's judgement on the merits (although it considered that, for the same reason, some low-tide elevations are part of the EEZ of the Philippines). It appears that these statements only constitute obiter dictum, and that such indication by the Tribunal neither binds the Philippines nor the PRC as a matter of res judicata, and much less Taiwan, which is neither Party to the contentious case nor Party to the UNCLOS, or even Japan. This is a logical reasoning for judging on Tribunal's jurisdiction to deal with the status of a rock. In the Dispositif of the Award, no name of other islands in the scs is mentioned except for those of the features the Philippines raised as objects of issue. The definitive conclusions of the Award bind China and the Philippines only.

For all that, it is to be doubted whether it is well-advised for the Prime Minister Abe and his Cabinet Office of Japan to politically urge the PRC for observing the Tribunal's Award which contains such new tests of an island and rocks.

\footnotetext{
44 The Tribunal briefly mentioned the 2009 case on the Black Sea maritime delimitation, e.g. with connection to the Philippines' submission on the proposed tests of rocks. Tribunal's Award (merits) para. 420.

45 See, e.g. Maritime Delimitation in the Black Sea (Romania v. Ukraine), Judgment, 2009 ICJ para.18o (3 February).

46 Tribunal's Award (merits), x. Despositif, para.1203, B. (7) a. and b (at 474).

47 Tribunal's Award paras. $580-584$.
} 
It would produce a backlash against or at least make a reciprocal impact on Japan's position regarding Okinotorishima, or the Douglas Atoll. ${ }^{48}$ While, generally speaking, the international cases do not have stare decisis, the Tribunal's interpretation or definition of 'rocks' in Article 121, Paragraph 3, would exert a critical influence on the jurisprudence of the international courts in future as well as on the position or policy of States Parties to the UNCLOS.

Provided that the detailed tests of the Award should be applied, you see little possibilities that, apart from the coastal islands, an oceanic, offshore remote island like Okinotorishima (the Douglas Atoll), would be regarded as an exception, even if there was a (failed) attempt to build a lighthouse on it in 1940 or the former practice establishing a 200-mile fisheries zone around it for the period of 1977-1996. Not only the outer continental shelf beyond 200 miles but also the inner (200-mile) continental shelf of Okinotorishima has come to be questioned as a matter of compatibility with the common heritage of mankind or the Deep Seabed regime. It is only too important for policy makers on maritime matters to take note of the changing trend of jurisprudence in international law. The alternatives for Japan would be either to transform its maritime claim and laws so as to contribute furthermore to the Deep Seabed regime, or otherwise to relinquish all except for territorial waters.

The Tribunal's tests of an island and rocks has made it impossible to claim the EEZ or continental shelf even if there have been traditional fisheries or exploitation of guano as extractive economic activity in historical record, which does not qualify as economic life of their own. Those activities would not constitute evidence for historic rights. This is the case with respect to the capacity of Douglas Atoll (Okinotorishima) and Itu Aba Island (Tàipíng Dăo) in the natural state. The gist of the scs Award by the Arbitral Tribunal consists in that, so long as they remain Parties to the UNCLOS, the States which have in fact controlled a maritime feature ought to establish no maritime zones around it or to exercise no jurisdiction over them in such a manner as undermining the object and purpose of any particular article of the UNCLOS.

After all, the nine-dash-line is an outer delimitation line of self-proclaimed maritime zones based on China's historic rights in the scs. However, it is

48 Cf. Ryota Kaji, okinotorishima wo meguru shomondai to nishitaiheiyo no kaiyo anzen hosho [the questions regarding the Douglas Atoll (Okinotorishima) and the maritime security in the Western Pacific], 321 rippo to chosa [Legislation and Research] (October 2011). 
neither historic waters nor internal waters. This has been only a goal of the PRC's maritime policy, so long as no domestic law was enacted, in particular relating to the SCs, or no attempt was made to exercise actual control over the features or reclaim land from underwater reefs.

As for the tests of an island and rocks, if it had been applied in the Jan Mayen case, Norway's Jan Mayen Island, which did not have any local community of people except for governmental officials, would not have the capacity for human habitation or economic life of their own, and so it would have had no entitlement to the EEZ or continental shelf. However, the 1993 classic judgement of the ICJ on the maritime delimitation between Greenland and Jan Mayen fully recognized the status of an island and the entitlements to the 200-mile fisheries zone (part of the current EEZ), dividing the interstitial zone into three subzones on the basis of a median line in favour of Denmark, given the comparative assessment of the mutual length of coastal lines and the distribution range of fishery resources in accordance with the law of the sea at that time. ${ }^{49}$ However, the jurisprudence of the international courts or tribunals has evolved and gradually transformed itself since the coming into force of the UNCLOS. In the 2009 judgement on the maritime delimitation of the Black Sea, finally, although avoiding the direct interpretation of 'rocks' in Article 121, paragraph 3 , the ICJ considered that it would be able to restrict or ignore the effect or role of a minute islet, provided that it creates a grossly 'inequitable effect' to the purpose of achieving an equitable solution. The ICJ in fact ignored the existence of an islet which remained beyond Ukraine's 12-mile territorial waters but within the 200 miles from the Ukrainian mainland coast (a possible EEZ around the islet) and on which there was only a lighthouse. ${ }^{50}$

As examined above, the Tribunal's Award directly and in details interpreted Article 121, paragraph 3, and suggested an unprecedented tests of an island and rocks (without distinguishing high-tide maritime features). Unfavourably to States Parties to the UNCLOS retaining a rather conservative approach, it appears that the jurisprudence of international courts or tribunals has already begun to make a complete, definite transition to such restrictive approach with respect to Paragraph 3. And what is worse, from the Japanese perspective, it would be impossible to emulate the us practice on this issue, for the

49 Maritime Delimitation in the Area between Greenland and Jan Mayen (Denmark v. Norway), Judgment, 1993 ICJ 38 (14 June).

5o Maritime Delimitation in the Black Sea (Romania v. Ukraine), Judgment, 3 February 2009 ICJ, paras.185-186 (3 February), and see Rothwell And Stephens, supra note 33 at 437-439. 
US is not a party to the UNCLOS. Indeed, the Us Government could maintain a 200-mile EEZ around the Johnston Atoll several hundred miles away from Hawaii, where even military officials no longer inhabit there because of conspicuous environmental damages, or around the Kingman Atoll at far northeastern sea of the American Samoa, in accordance with the former international conventions and customs. Japan, however, might not be able to maintain such maritime zones unless it will contend for exception on the appropriate grounds under general law or persuade the adjacent, coastal States involved to reach a new agreement and establish a new local maritime regime' with due regard to the Deep Seabed regime and the common heritage of mankind, ${ }^{51}$ partially modifying or suspending part of the UNCLOS so that they could co-operate in creating a new local order of law of the sea amongst them in accordance with Article 311, paragraph 3, of the UNCLOS.

Japan's claims for the southern part of the outer continental shelf beyond 200 miles around the Douglas Atoll (Okinotorishima) might infringe on the common heritage of mankind, ${ }^{52}$ while, in any case, it could be bound by Article 82 on the payments and contributions in kind in respect of exploitation. As per the 200-mile inner continental shelf of the Douglas Atoll, it remains to see whether a more sophisticated attempt will be made in the jurisprudence of the international courts to find a well-balanced and more practical test of the continental shelf for achieving an equitable solution. Taiwan was only the victim of the Tribunal's Award, so to speak, and it would have been ill-advised for the PRC to continue absence and did not assert its position at courtroom even after the Tribunal's unfavourable judgement on jurisdiction and admissibility (29 Oct. 2015), ${ }^{53}$ save for a dire statement such as 'waste paper'.54

On the other hand, despite the aforesaid trend of change in case law, Japan's MOFA position or interpretation of Article 121 is without doubt extraordinarily singular. It has not changed ever since 30 years ago, and unfortunately it would

$5^{1}$ It is to be noted that the Parties to the UNCLOS shall not derogate from the basic principle (or the object and purpose) relating to the common heritage of mankind (Article 311, paragraph 6).

$52 \quad$ Tribunal's Award (merits) para. 419 and para. 624.

53 In the Matter of an Arbitration (Philippines v. PRC), Award of 29 October 2015, An Arbitral Tribunal Constituted under Annex viI to the 1982 UN Convention on the Law of the Sea (Registry: Permanent Court of Arbitration, PCA Case No. 2013-19).

54 In a tough speech in Washington last week, a former senior Chinese official, Dai Bingguo, said that the findings would amount to no more than 'waste paper.' Jane Perlez, Tribunal Rejects Beijing's Claims in South China Sea, New Yor T Times, 12 July 2016. 
rather be illogical or no longer helpful than has gone out of date..$^{55}$ Meanwhile, Japan has never invoked even historic-rights-type grounds as the basis of its entitlements to the continental shelf around Okinotorishima (the Douglas Atoll). As already mentioned, Japan could not emulate the us practice with respect to that Atoll, provided that it remains the State Party to the UNCLOs. The two high-tide minute rocks on the Atoll, indeed, were literally named 'North Rock' and 'South Rock' respectively for a long time, while they are now figuratively named 'North Island' and 'South Island' in an official hydrographic chart. It is to be noted that it would take much more time for Japan to navigate its way to a new position. About time, too.

55 Japan's Ministry of Foreign Affairs, twelve years ago, explained as follows: Status of Okinotorishima island(Japan's mofA, Press Conference, 18 February 2005): '... The island, under the Tokyo Municipal Government, has been known as an island under Japanese jurisdiction since 1931, long before the United Nations Convention on the Law of the Sea came into existence. Having ratified the Convention in 1996, Japan registered its domestic laws concerning its territorial waters, in which Okinotorishima is included as an island, to the Secretary-General of the UN in 1997. Seven years passed without a single claim. As recently as in 2004, a research vessel of a certain country, having violated Japan's Exclusive Economic Zone (EEZ) by ignoring necessary procedures, was asked why it took the liberty to do so. It justified its trespassing on grounds that they construed Okinotorishima as a rock. Article 121 of the United Nations Convention on the Law of the Sea defines that "an island is a naturally formed area of land, surrounded by water, which is above water at high tide." This is exactly what Okinotorishima is. In the same Article, there is a paragraph stating that "rocks which cannot sustain human habitation or economic life of their own shall have no EEZ or continental shelf." This paragraph talks about a rock which is [un] inhabitable and does not define what an island is. The definition of an island is spelled out in Paragraph 1 , and there is no room for lay interpretation and this does not serve as a pretext for arbitrary intrusion. Vessels of a single country have been repeatedly trespassing, 18 times in the Pacific and as often as nine times around Okinotorishima alone, by defining the nature of foreign soil at their discretion. [emphasis added]' [available at: http://www.mofa.go.jp/announce/press/2005/2/o218.html\#3]. 


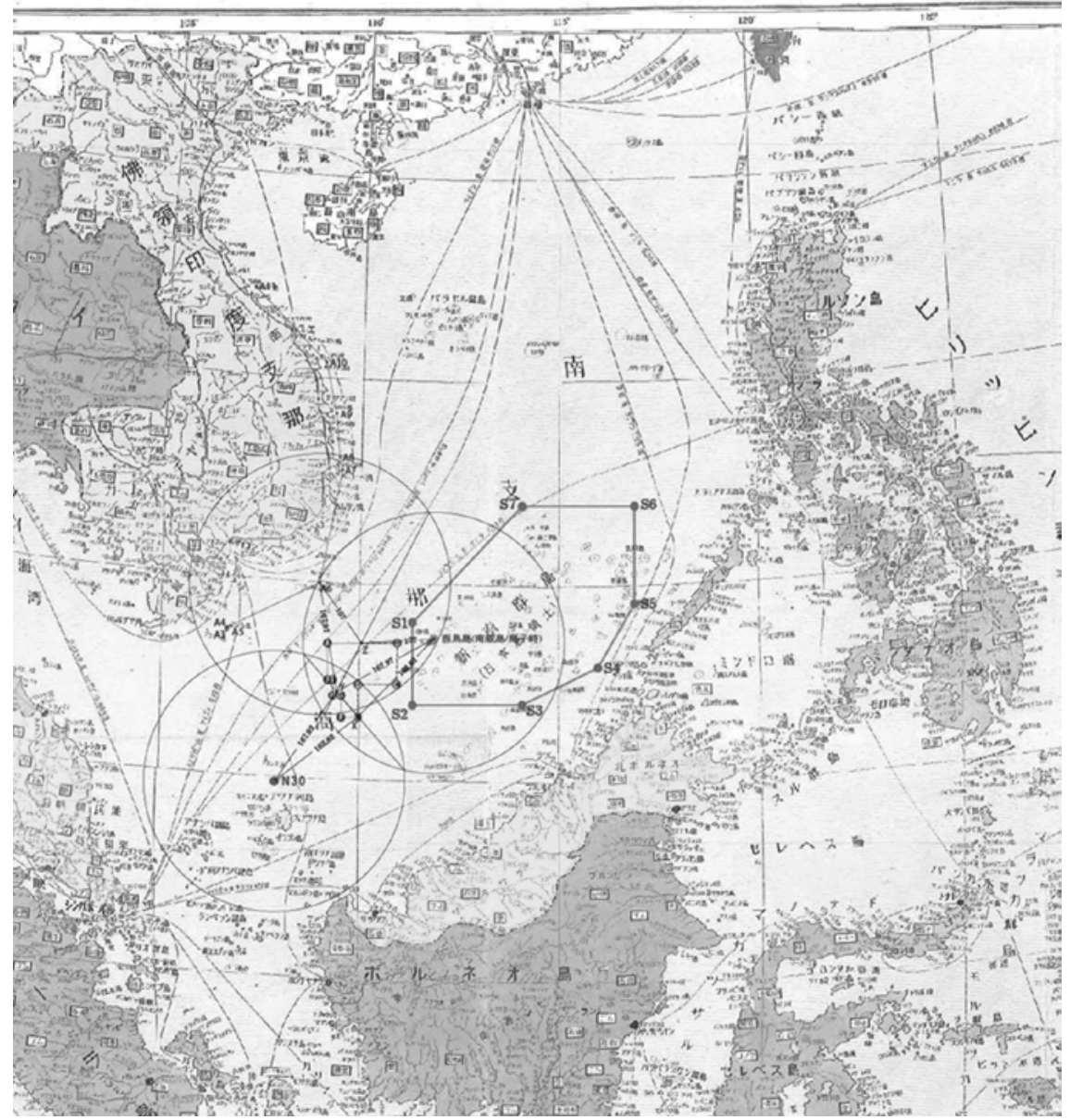

MAP 8.1 Japan's 'New Southern Islands' (1939) [Spratly Islands]

(@ KINREISHA, 15 DEC. 1940) RAN-IN (NANYO) OYOBI FUTSUIN ZENZU

[COMPLETE MAP OF DUTCH INDIA (SOUTHERN SEA) AND FRENCH INDIA]

Notification No.122, Government-General, Taiwan (Japan), 3о March 1939

S1 9 degrees Latitude (North)/11 1 degrees 30 minutes Longitude (East)

S2 7 degrees North $/ 11$ degrees 30 minutes East

S3 7 degrees North $/ 114$ degrees East

$\mathrm{S}_{4} 8$ degrees North/116 degrees East

$\mathrm{S}_{5} \quad 9$ degrees 30 minutes North $/ 117$ degrees East

S6 12 degrees North $/ 117$ degrees East

$\mathrm{S}_{7} 12$ degrees North/114 degrees East 